\title{
PERKembangan taman Kota di bandung MAsa hINDIA BELANDA (1918-1942)
}

\section{CITY PARK DEVELOPMENTS IN BANDUNG IN DUTCH EAST INDIES ERA (1918-1942)}

\author{
Hary Ganjar Budiman \\ Balai Pelestarian Nilai Budaya (BPNB) Bandung \\ Jl. Cinambo No. 136, Ujungberung-Bandung \\ email: hgbudiman@gmail.com
}

\begin{abstract}
Abstrak
Penelitian ini berusaha menguraikan tentang perkembangan taman kota serta analisis persebarannya di Bandung pada masa pemerintahan Hindia Belanda. Penelitian ini penting untuk dilakukan agar diketahui contoh pola perancangan taman kota yang baik dalam perkembangan kota. Penelitian ini menggunakan metode sejarah (heuristik, kritik, interpretasi, dan historiografi) dengan pendekatan sosio-spatial. Adapun konsep yang digunakan adalah "dialektika sosiospatial", yaitu di suatu sisi masyarakat menciptakan dan memodifikasi ruang-ruang perkotaan namun di sisi lain, pada saat bersamaan, berbagai ruang berusaha disesuaikan agar sesuai dengan ruang-ruang tempat mereka tinggal dan kerja. Melalui penelitian ini diketahui bahwa pembangunan tamantaman kota dipengaruhi oleh peranan elit Eropa (Preangerplanters dan pejabat pemerintah) di Bandung. Pembangunan taman kota terjadi sepanjang tahun 1918 hingga 1925 bersamaan dengan rencana perpindahan ibu kota Hindia Belanda ke Bandung. Taman kota dibangun sebagai fasilitas publik yang berada di dekat lingkungan pendidikan, perumahan, dan pemerintahan. Pengambil kebijakan di masa itu menyadari pentingnya penyediaan ruang hijau ketika jumlah penduduk dan kehidupan kota semakin berkembang.
\end{abstract}

Kata kunci: Taman kota, Bandung, preangerplanters, kota kolonial.

\begin{abstract}
This study tried to describe the development of the city park and the analysis of their distribution in Bandung during the reign of the Dutch East Indies. This research is important to do in order to know the examples of design pattern of a city park in both of the development of the city. This study uses historical methods (heuristic, criticism, interpretation, and historiography) with socio-spatial approach. The concept used in this research is the "dialectic sosiospatial" ; a society creates and modifies the urban spaces, but on the other hand, at the same time, a variety of space is tried to be adjusted to fit the spaces where they live and work.Through this research, can be inferred that the construction of city parks affected by the role of the European elite (Preangerplanters and government officials) in Bandung. City park development occurs throughout the 1918 to 1925 along with plans to transfer the capital of the Dutch East Indies to Bandung. City Park was built as a public facility that was located near an educational environment, housing, and governance. Policy makers at the time realized that the importance of providing green space when the population of city life is growing.
\end{abstract}

Keywords: City park, Bandung, preangerplanters, colonial city. 


\section{A. PENDAHULUAN}

Sepanjang pertengahan tahun 2014 hingga 2015, pemerintah Kota Bandung gencar membangun taman-taman kota ${ }^{1}$. Taman yang dibangun tentu saja bisa bermanfaat untuk meningkatkan kualitas udara dan menjaga sistem hidrologis, lebih jauh dari itu, taman menyediakan ruang yang menyenangkan untuk masyarakat melepas penat dari rutinitas kota. Lahan hijau seperti taman, penting bagi penduduk kota agar mengalami perasaan saling berhubungan dengan alam dan memahami bahwa umat manusia membentuk suatu bagian integral dari alam. Dengan keberadaan taman, orang dapat mengubah pandangannya terhadap alam, masyarakat dapat berjalan-jalan, mendengarkan kicau burung, beristirahat setelah kerja (Nas, 2007). Dilihat dalam konteks yang lebih luas, taman sebagai salah satu bentuk ruang hijau dapat merepresentasikan keberadaban sebuah kota; di mana perkembangan kota yang sarat dengan teknologi, tak bisa begitu saja mengabaikan keseimbangan alam, juga keseimbangan psikologis manusia perkotaan untuk tetap terhubung dengan alam tersebut.

Khususnya di Kota Bandung, kesadaran akan pentingnya ruang-ruang hijau di tengah perkembangan masyarakat kota sudah terjadi dan dimulai sejak masa Hindia-Belanda. Dalam persoalan pengembangan rencana kota saat ini, khususnya jika pembangunan itu akan diorientasikan pada ruang-ruang terbuka hijau, agaknya menjadi perlu untuk menggali kembali sejarah munculnya taman-taman kota di Bandung. Studi tentang sejarah taman menjadi menarik, karena Bandung di masa Hindia-Belanda

\footnotetext{
* Sebagian besar data dari artikel ini diambil dari skripsi penulis dengan beberapa penambahan pada data dan analisisnya.

${ }^{1}$ http://regional.kompas.com/read/2014/09/16/1 3041431/janji.ridwan.kamil.untuk.tahun.2015. dari.taman.sampai.monorel, diakses 25 Februari 2015.
}

merupakan suatu contoh ideal kota kolonial $^{2}$ yang dirancang dengan kecermatan konsep tuinstad (kota taman)

Berdasarkan pada penelitian dan tulisan-tulisan terdahulu yang terkait dengan taman kota di Bandung, penulis menemukan bahwa buku karya Haryoto Kunto, Semerbak Bunga di Bandung Raya (1986) merupakan sumber acuan yang menyediakan banyak data terkait pembangunan lahan hijau di Bandung masa Hindia Belanda. Mengingat gaya penulisannya yang cenderung populer, buku tersebut masih minim analisis dan secara kronologis belum terjelaskan latar belakang pembuatan taman-taman kota di Bandung. Sumber lain yang relevan untuk artikel ini adalah disertasi Sobana Hardjasaputra, Perubahan Sosial di Bandung 1810-1906 (2002). Disertasi tersebut memberikan penjelasan yang komprehensif terkait andil pemerintah Belanda, golongan menengah Eropa, dan penguasa pribumi di Bandung dalam mengembangkan infrastruktur kota, termasuk mengembangkan kepariwisataannya. Acuan lain yang memiliki signifikansi penting dalam tulisan ini adalah tesis yang dibuat Suhardi Maulana, Seremban Urban Park, Malaysia: A Preference Study (2002). Tesis tersebut memberikan model sekaligus menjelaskan konsep taman kota yang pada masa lampau dipahami oleh orang-orang Eropa.

Mengacu pada hal-hal yang dikemukakan di atas, tulisan ini dibuat untuk mengetahui bagaimana perkembangan taman kota di Bandung, khususnya pada awal abad ke- $20^{3}$ hingga

2 Menurut Peter J.M. Nas, kota kolonial mempunyai beberapa ciri, yaitu berorientasi ke Barat, mempunyai fungsi sebagai pusat perekonomian dan pemerintahan, serta pemisahan kelompok-kelompok penduduk berdasarkan latar belakang etnisnya (Nas, 2007: 305).

${ }^{3}$ Umum diketahui model-model kota kolonial di Hindia Belanda seperti Malang, Surabaya, Semarang, termasuk pula Bandung, mulai mengalami perkembangan pesat dalam 
akhir kekuasaan Pemerintah Hindia Belanda. Adapun dalam penguraiannya, tulisan ini juga akan membahas dan melacak awal mula dikenalnya konsep taman oleh masyarakat Eropa sebagai pihak yang membawa dan mewujudkannya di tanah jajahan. Hal ini penting untuk mengetahui pemahaman taman dalam alam pikir orang-orang Eropa. Berdasarkan hal tersebut, nantinya dapat pula diketahui pola perancangan taman dilihat dari perancangan Kota Bandung secara keseluruhan. Perancangan kota Bandung juga akan memberikan gambaran, bagaimana orang-orang Eropa di Bandung memandang alam atau lahan hijau.

\section{B. METODE PENELITIAN}

Tulisan ini menggunakan metode sejarah yang meliputi empat tahapan kerja. (1) tahap heuristik, yaitu pengumpulan sumber. Dalam hal ini lebih difokuskan pada sumber primer berupa peta Bandung tahun 1933 dan sumber arsip Gemeente Bandung, serta didukung sumber-sumber sekunder berupa buku. (2) tahap kritik yaitu mengkaji otentisitas sumber dan kredibilitas sumber. (3) tahap interpretasi, yaitu menafsirkan fakta-fakta serta menetapkan makna dari serangkaian fakta yang diperoleh. (5) tahap historiografi yaitu rekonstruksi yang imajinatif masa lampau berdasarkan data yang diperolah dengan menempuh proses menguji dan menganalisis secara kritis rekaman dan peninggalan masa lampau (Lubis, 2011:15).

Untuk memperjelas dan mempertajam analisis, tulisan ini menggunakan konsep urban park. Mengacu pada tulisan Yuen (dalam Maulana, 2002: 9), urban park as any public area of land set aside for aesthetic, educational, recreational or cultural use by the public amidst essentially urban

pembangunan kota seiring makin mapannya politik ekonomi terbuka. Banyak pengusaha Eropa datang dan menetap di Hindia Belanda, dan secara tak langsung mendorong kehidupan perkotaan, khususnya di awal abad ke-20. surroundings. Adapun dalam analisis data, tulisan ini menggunakan pendekatan spatial yang dikemukakan oleh Soja (dalam Kuper, 2000). Ia memperkenalkan konsep "dialektika sosiospatial", yaitu di suatu sisi masyarakat menciptakan dan memodifikasi ruang-ruang perkotaan namun di sisi lain, pada saat bersamaan, berbagai ruang berusaha disesuaikan agar sesuai dengan ruang-ruang tempat mereka tinggal dan kerja. Mengamati persoalanpersoalan perkotaan, termasuk dalam mengamati taman kota, perspektif spasial berguna untuk digunakan. Penyekatan ruang melalui penetapan batas-batas teritorial menyiratkan pentingnya atribut spasial yang memiliki akibat-akibat langsung terhadap berbagai bidang kehidupan perkotaan (Budiman, 2010: 14).

\section{HASIL DAN BAHASAN}

\section{Awal Mula dikenalnya Konsep Taman}

Selama masa kolonisasi pada akhir abad ke-19, orang-orang Eropa memperkenalkan konsep taman kota ke Asia. Pada awal abad ke-20 kota-kota seperti Manila, Hongkong, Singapur, dan Kuala Lumpur yang merupakan bagian koloni Inggris, telah memiliki tamantaman kotanya sendiri (Maulana, 2002: 2). Hindia Belanda sebagai wilayah koloni Kerajaan Belanda, tentu saja memiliki kondisi yang hampir serupa, dan jejak dikenalnya taman di Hindia Belanda bisa dilacak sejak abad ke-17 dan 18.

Semenjak VOC menetapkan kekuasaan dagangnya di Batavia, atau terhitung semenjak kedatangan Jan Pieterzoon Coen pada 1619, orang-orang Belanda mulai mendirikan benteng dan membangun kehidupan di Batavia. Kehidupan di dalam Benteng ditinggalkan pada abad ke-18, orang-orang Belanda atau pun pejabat VOC mulai membangun rumah-rumah peristirahatan dan taman yang luas (landhuis) di luar benteng. Mereka berbaur dengan orang pribumi dan penduduk pendatang dari timur asing, namun demikian orang-orang Belanda tetap membangun tempat tinggal dengan 
konsep yang mirip dengan negara asalnya (Soekiman, 2011: 2). Eksistensi awal taman di Batavia bisa diamati dari lukisan John Rach tahun 1764 yang melukis Rumah Reinier de Klerck. Dalam lukisan Rach tergambar halaman rumah Reiner de Klerck yang terdapat taman dengan bungabunga yang Indah (Soekiman, 2011: 102). Melalui lukisan tersebut dapat diketahui bahwa pada awalnya taman dibangun untuk kenyamanan pribadi seseorang, atau orang-orang yang memiliki kedudukan penting seperti misalnya seorang Gubernur Jenderal. Hal ini sejalan dengan konsep perancangan taman di Eropa pada abad ke17 diperuntukkan bagi Raja.

John Claudius Loudon dalam bukunya An Encyclopeadia of Gardening mengungkapkan bahwa kuatnya tradisi taman di Eropa bisa dilihat sejak era Louis XIV. Pada masa itu, dengan mengambil contoh taman Versailles, taman menyimbolkan dominasi laki-laki, manipulasi alam untuk menunjukkan kekuasaan, kekayaan dan kekuatan (Roger, 2001). Taman Versailles digunakan khusus untuk kalangan kerajaan, atau untuk kesenangan Raja Louis pribadi, contohnya pada 1664, Louis XIV merayakan festival selama enam hari di taman, dengan iringiringan, komedi, balet, dan kembang api (Roger, 2001: 165-167).

Selepas Revolusi Prancis, cara pandang orang Eropa terhadap alam semakin kaya, salah satunya dipengaruhi oleh pemikiran Jean-Jacques Rousseau lewat tulisannya yang berjudul "Nobility of Nature" pada 1762. Ia pun mengimajinasikan persepsinya tentang keindahan taman yang sempurna melalui novelnya yang berjudul La Nouvelle Heloise. Gambaran taman dalam novel tersebut, kemudian menjadi model dalam perancangan taman di Prancis (Roger, 2001: 165-167). Hampir serupa dengan Prancis, di negeri besar seperti Inggri muncul pula para pemikir yang memunculkan ide-ide tentang taman; pada 1803 Humphrey Repton mengemukakan idenya tentang harmonisasi taman dengan lahan-lahan di sekelilingnya melalui bukunya Observations on the Theory and Practice of Landscape Gardening (1803), Ebenzer Howard yang mengemukakan idenya tentang kota taman melalui bukunya yang berjudul Tomorrow, a Peaceful Path to Real Reform (Kunto, 1986: 206).

Memasuki abad ke-19 manakala revolusi industri bergulir dengan kencang di Eropa, kota-kota besar mulai disesaki oleh industri dan perumahan-perumahan kumuh, mulai terjadi pergeseran fungsi taman; sebelumnya digunakan untuk taman pribadi di kalangan bangsawan/raja, kemudian muncul gagasan untuk digunakan oleh masyarakat umum. Taman yang pertama kali dijadikan ruang untuk kepentingan publik adalah Regent Park yang digagas oleh John Nash. Ia merancang konsep taman atau landscape sebagai bagian dari tempat tinggal di lingkungan perkotaan. Pada 1827, Nash mengubah Regent Park, yaitu dengan menghubungkan jalur dalam taman dengan jalan di Westminister London dan mengubah tampilan kota secara umum. Jejak Nash ini kemudian diikuti oleh Joseph Paxton yang merancang ulang Prince Park di Liverpool menjadi taman publik pada 1843. Perancangan Prince Park menjadi pengaruh yang besar dalam design landscape taman di perkotaan. Ide Joseph Paxton kemudian diadopsi oleh Frederick Law Olmsted dalam merancang Central Park New York pada $1857^{4}$. Perancangan taman dengan nuansa Romantik Eropa sangat popular di Inggris pada akhir 1800-an yang sejalan dengan trend taman kota berkonsep "Pleasure Ground" yang popular di Amerika pada 1850 hingga 1900 (Maulana, 2002:4).

Di negeri Belanda terdapat pula taman-taman tertua, di antaranya adalah Hortus Botanicus Amsterdam yang didirikan pada 1638 untuk kebutuhan medis atau pengobatan, Frankedael Park

\footnotetext{
${ }^{4}$ http://www.manchester2002uk.com/daytrips/parks-gardens.html, diakses 4 Juni 2015
} 
telah ada sejak abad ke-18 yang dibangun sebagai halaman rumah pribadi Nicolaas van Liebergen. Terdapat pula Sarphatipark dan Wertheimpark. Taman yang disebut terakhir ini merupakan salah satu taman tertua di Amsterdam, dibangun pada 1812 yang merupakan hadiah pemberian Napoleon untuk Amsterdam. Pada 1849 Wertheimpark ${ }^{5}$ digunakan sebagai tempat hiburan, kemudian pada 1897 ditetapkan sebagai taman umum.

Ide-ide tentang perancangan taman memang meluas pada awal abad ke-19, meliputi Amerika, Inggris, dan daratan Eropa. Kota-kota di Swedia, Denmark, dan Belanda mulai mengembangkan taman kota untuk meningkatkan kualitas kotanya (Maulana, 2002: 1). Menyebarnya trend pembuatan taman agaknya harus dilihat dalam konteks upaya pembenahan kota manakala dampak revolusi industri semakin terasa. Taman diperlukan untuk menjaga kualitas kehidupan di perkotaan. Konsep berpikir ini kemudian turut berimbas pada pembuatan taman-taman kota di negara jajahan ${ }^{6}$, seperti di Hindia Belanda. Ketika politik Pintu Terbuka diberlakukan sejak 1870, orang-orang Eropa semakin banyak datang ke Hindia Belanda untuk merintis bisnisnya dan membangun kehidupan baru. Tentu saja cara pandang orang Eropa di tempat asalnya dibawa dan berusaha diwujudkan di tempat barunya agar mereka bisa menetap dengan nyaman. Singkatnya, orang Eropa membawa budaya dari tempat asalnya, kemudian disesuaikan dengan kondisi di Hindia Belanda, termasuk dalam pembangunan rumah tinggal, perancangan perkotaan (termasuk pembuatan tamantaman), bahkan perilaku dalam kehidupan sehari-hari.

\section{Latar Belakang Pembangunan Taman Kota di Bandung}

${ }^{5}$ http://www.europecities.com/en/786/netherlan ds/amsterdam/place
Memasuki akhir abad ke-19 dan menjelang abad ke-20, kehidupan di Bandung semakin dinamis, sarana dan prasarana semakin lengkap. Hal ini terkait dengan wilayah Bandung yang dikenal subur dan potensial secara ekonomi sebagai lahan-lahan usaha perkebunan (salah satunya komoditi kopi). Agar laju ekonomi perkebunan bisa berjalan baik, maka diperlukan transportasi dan fasilitas rumah tinggal yang memadai, termasuk sarana lainnya untuk menunjang kehidupan para pengusaha Eropa yang dikenal sebagai preangerplanters (Hardjasaputra, 2002). Para preangerplanter ini yang kemudian lebih banyak mengambil peran dalam pembenahan kota. Tentu hal ini bisa dipahami, dengan kekuatan ekonomi yang mereka miliki, para preangerplanter sebagai golongan elit-bersama pejabat pemerintahan - di kota, ingin mewujudkan kehidupan yang nyaman. Definisi nyaman dalam hal ini bisa berarti sesuai dengan ukuran-ukuran mereka di tempat asalnya (Eropa).

Melihat besarnya potensi dari para preangerplanter ini, Asisten Residen Pieter Sijhoff menggagas pembentukan Vereeniging tot nut van Bandung en Omstreken (Perkumpulan Kesejahteraan Masyarakat Bandung dan Sekitarnya) pada 1898. Anggota organisasi tersebut terdiri dari para pengusaha Eropa terkemuka di Bandung $^{7}$. Organisasi yang digagas oleh Pieter Sijhoff tersebut, sejak 1898 hingga 1906 telah melakukan beberapa pembenahan kota, antara lain memerlukan penambahan jalur jalan, pembangunan fasilitas pendidikan, peningkatan mutu rumah tinggal, pemindahan pekuburan orang-orang Eropa dan Cina, pembangunan Societat Concordia

\footnotetext{
${ }^{7}$ Anggota Vereeniging tot nut van Bandung en Omstreken, di antaranya adalah Keluarga Soesman, keluarga Roeman, keluarga V. D. Wijck, R.A. Kerkhoven, K.A.R. Bosscha, Schenk, Melinger, J.H. Bessem dari, B. Th. Neervoort, F.W. Brinkman, dan W.A. del Val dari Negla (Kunto, 1984: 41).
} 
(sekarang dikenal sebagai Gedung Merdeka), pembangunan pasar baru, dan penyediaan sarana kereta kuda sebagai pengganti pedati (Kunto, 1984: 75).

Mengacu pada buku Semerbak Bunga di Bandung Raya (1986) dapat diketahui bahwa peran elit Eropa sangat menentukan dalam pembenahan kota. Pemerintah, dalam hal ini Asisten Residen memberi ruang sekaligus bersinergi dengan preangerplanter dalam membangun kehidupan kota yang layak melalui organisasi sosial kemasyarakatan ${ }^{8}$. Besarnya porsi golongan Eropa dalam pembenahan kota dapat dilihat dari berdirinya taman kota pertama di Bandung, yang merupakan suatu bentuk penghargaan terhdap jasa Asisten Residen Pieter Sijhoff. Pada 1885 berdiri taman kota pertama di Bandung dengan nama Pieter Sijhoff Park, diambil dari nama sang Asisten Residen (Kunto, 1984;114).

Taman yang menjadi salah satu sarana untuk menunjang kenyamanan kehidupan orang-orang Eropa di Bandung pada akhirnya terlihat begitu diperlukan. Salah satu buktinya terlihat dari potongan dokumen dari Verslag van der Toestand der Gemeente Bandoeng over de Jaren 1906/198: Staat van Uitgaven van de Gemeente Bandoeng over de Dienstjaren 1906 t/m 1918. Kutipan dokumen tersebut menunjukkan anggaran khusus untuk pemeliharaan tanaman, jalan, dan lapangan luas (ditulis dalam bahasa Belanda,

8 lebih jauh lagi, organisasi kemasyarakatan yang notabene terdiri dari golongan elit Eropa terus berkembang menjadi Bandoeng Vooruit pada 1925. Kepengurusannya memadukan pejabat pemerintah Belanda, preangerplanters, dan bupati. Organisasi Bandoeng Vooruit ini didirikan atas inisiatif Perhimpunan Golongan Menengah Muda Eropa (De Nog Jonge Midden-stands-vereeniging). Para pejabat pemerintah dilibatkan secara langsung dalam aktivitas organisasi ini, hal ini bertujuan agar pemerintah pribumi maupun pemerintah kolonial turut serta memperhatikan potensi wisata di wilayahnya (Hardjasaputra, 2006: 23). "plein"9). Tabel berikut menunjukkan angka jelas dan telah diterjemahkan dalam bahasa Indonesia, tentang anggaran pemerintahan otonom Bandung (gemeente Bandoeng) yang terkait dengan pemeliharaan lahan hijau. Walaupun tidak eksplisit disebutkan anggaran untuk pemeliharaan taman kota, namun tidak menutup kemungkinan dua jenis pengeluaran tersebut, termasuk pula dalam pemeliharaan taman. Hal ini dikuatkan oleh pertambahan pengeluaran dari tiaptiap tahunnya, berbanding lurus dengan kemunculan taman-taman kota kemudian.

Tabel 1.Catatan Keuangan Gemeente Bandoeng Tahun 1906-1918

Tahun

Tugas-tugas Gemeente

\begin{tabular}{ccc} 
& $\begin{array}{c}\text { Pemeliharaan } \\
\text { jalan dan } \\
\text { lapangan }\end{array}$ & $\begin{array}{c}\text { Konstruksi } \\
\text { dan } \\
\text { pemeliharaan } \\
\text { tanaman }\end{array}$ \\
\hline 1906 & 20.980 & --- \\
\hline 1907 & 21.480 & --- \\
\hline 1908 & 26.050 & --- \\
\hline 1909 & 23.20 & --- \\
\hline 1910 & 41.000 & --- \\
\hline 1911 & $---*)$ & --- \\
\hline 1913 & 61.720 & --- \\
\hline 1914 & 66.870 & 2.670 \\
\hline 1915 & 77.750 & 2.350 \\
\hline 1916 & 99.675 & 3.520 \\
\hline 1917 & 109.370 & 9.400 \\
\hline 1918 & 116.000 & \\
\hline & & - \\
\hline
\end{tabular}

${ }^{9}$ Kata plein dalam bahasa Belanda biasanya diidentikkan sebagai lapangan yang luas untuk aktifitas, bisa pula berupa hamparan rumput yang luas. 
Sumber: Verslag van der Toestand der Gemeente Bandoeng over de Jaren 1906/198: Staat van Uitgaven van de Gemeente Bandoeng over de Dienstjaren 1906 t/m 1918).

Keterangan: berdasarkan mata uang Gulden

*): Data dalam sumber tidak menunjukkan angka yang jelas.

Bagi para pengusaha Eropa keberadaan tempat-tempat hiburan, sarana rekreasi, dan tempat makan di kota dirasa sangat penting, mengingat waktu mereka lebih banyak digunakan di perkebunan sekitar dataran tinggi Bandung. Manakala akhir pekan atau waktu kosong tiba, orangorang Eropa ini pergi menuju kota dan menikmati fasilitas yang ada sebagai bagian dari penyegaran atas rutinitas yang dilakukannya. Keberadaan Pieter Sijhoff Park menjadi contoh nyata bagaimana taman digunakan untuk melepas penat. Karena letaknya yang berdekatan dengan Kweekschool, taman ini sering digunakan pelajar ketika istirahat siang. Para pemain drumband tentara Belanda pun sering berlatih di Pieter Sijhoff Park. Bagi para preangerplanter, Pieter Sijhoff Park digunakan pula sebagai tempat mendengarkan orkes musik sambil makanmakan (Kunto, 1984: 114).

Kebutuhan fasilitas kota, termasuk pula kebutuhan akan taman-taman makin dirasa manakala pertambahan penduduk Eropa di Bandung semakin tinggi. Pertambahan penduduk Eropa ini dipengaruhi oleh perekonomian dunia yang semakin maju. Bandung yang sangat potensial sebagai daerah perkebunan, semakin dituju oleh para pengusaha. Datangnya para preangerplanter, secara langsung mendorong kedatangan aparatur pemerintah dari Eropa. Hal ini mengakibatkan pertambahan penduduk Eropa. Sementara di sisi lain, gaya hidup serta pembangunan cenderung mirip ke gaya Eropa, dan kelas menengah tumbuh dengan cepat. Menurut J.M. Nas, kelas menengah ini ingin lebih berpengaruh, Kedatangan mereka menjadi salah satu faktor yang mengakibatkan berdirinya kota-kota praja yang berdasarkan undang- undang desentralisasi tahun 1903 (Soekiman, 2011: 36; Nas, 2007: 305).

Bagi Kota Bandung realisasi atas pembentukan kota praja terjadi pada 1906 ketika Bandung ditetapkan sebagai Gemeente $^{10}$. Ketika ditetapkan sebagai Gemeente, jumlah penduduk Eropa di Bandung meningkat cukup pesat. Tahun 1900, jumlah penduduk Eropa sebesar 1.522. Kemudian dalam jangka waktu lima tahun, yaitu pada 1905, jumlah penduduk Eropa mencapai 2.200 orang. Meski jika dibandingkan dengan jumlah pribumi dan penduduk Timur Asing, jumlah penduduk di Eropa lebih sedikit, namun karena mereka memiliki kekuatan dan kekuasaan secara politik dan ekonomi, maka golongan yang minoritas inilah yang justru banyak berpengaruh dalam penataan kota. Ditambah status Kota Bandung yang otonom, membuat kebijakan lebih banyak dipengaruhi golongan elit Eropa. Menurut Hardjasaputra, masyarakat Bandung ketika itu merupakan Een Western Enclave (sebuah enklave masyarakat Barat/asing), masyarakat Eropa menggunakan aturan sendiri, sedangkan masyarakat pribumi menggunakan sistem pemerintahan yang tetap mengacu pada hukum adat di bawah kepemimpinan Bupati (Hardjasputra, 2002: 275). Mengacu pada konsep yang dikemukakan J.M. Nas, Bandung merupakan Kota Kolonial, yaitu kota yang berorientasi ke Barat dan mempunyai fungsi sebagai pusat perekonomian dan pemerintahan (Nas, 2007: 305).

Kota Bandung memang berbentuk Kota Kolonial, hal ini ditegaskan dengan rencana pemindahan ibu kota Hindia Belanda dari Batavia ke Bandung, di mana perencanaannya telah dimulai sejak tahun 1918 hingga tahun 1925. Fokus pembangunannya pun diarahkan pada kepentingan orang-orang Eropa. Dalam

10 Pemerintah dengan sistem desentralisasi, bukan hanya desentralisasi dalam bidang keuangan, tetapi juga desentralisasi dalam pemberian hak otonomi bidang pemerintahan (zelfbestuur) (Lubis, 2000:127) 
kurun waktu tujuh tahun, Gemeente Bandung telah berhasil membangun 400 hingga 750 bangunan rumah modern yang direncanakan sebagai tempat tinggal para pegawai pemerintah pusat (Dienaputra, 2004: 18). Dari titik inilah bisa diasumsikan bahwa taman-taman kota merupakan bagian penting dalam rencana pemindahan ibu kota karena banyak taman yang dibangun dalam rentang waktu 1918 hingga 1925.

\section{Perkembangan Taman Kota}

Pembangunan taman-taman kota mulai terjadi dari tahun 1919 hingga sekitar tahun 1925. Melihat dari rentang waktu pembangunan taman-taman tersebut, besar kemungkinan bahwa kemunculannya memang sebagai salah satu komponen pendukung dalam penyediaan fasilitas, guna persiapan pemindahan ibu kota Hindia-Belanda ke Bandung yang berlangsung sepanjang 1918 hingga 1925. Asumsi ini bersandar pada persebaran taman-taman kota yang sebagian besar berdekatan dengan tempattempat strategis khususnya gedung-gedung pemerintahan, dan sebagian lainnya berdekatan dengan fasilitas pendidikan serta pemukiman masyarakat Eropa. Selain posisinya berdekatan dengan fasilitasfasilitas strategis, taman-taman kota dibangun pula dalam jangka waktu yang hampir bersamaan dengan pembangunan fasilitas-fasilitas tersebut ${ }^{11}$. Sangat masuk akal jika diasumsikan bahwa pembangunan taman-taman kota tersebut berbanding

\footnotetext{
11 Beberapa contoh yang nampak, antara lain pembangunan Ijzerman Park yang dibangun pada 1919, hampir bersamaan pula dengan pembangunan Technische Hoogeschool pada 1920. Sementara keduanya berada pada posisi yang memang berdekatan. Hal serupa dapat ditemui pada pembangunan Oranjeplein dan perumahan mewah, di Kapitein Hill. Keduanya, baik Oranjepelin maupun Kapitein Hill sama-sama dibangun pada 1920 dan dengan posisi yang saling berdekatan, bahkan saling melengkapi.
}

lurus dengan perkembangan pembangunan kota secara keseluruhan.

Belum ditemukan angka yang pasti mengenai jumlah taman kota yang ada selama masa pemerintahan Gemeente Bandoeng, namun berdasarkan dua buku karya Haryoto Kunto yaitu Bandoeng Tempo Doeloe dan Semerbak Bunga di Bandung Raya, serta mengacu pada majalah terbitan Bandoeng Vooruit, yaitu majalah Mooi Bandoeng, dapat diketahui bahwa pada masa pemerintahan kolonial, khususnya sepanjang tahun 1885 hingga 1925 , setidaknya Bandung memiliki lima buah taman kota yang cukup terkemuka, serta beberapa lapangan hijau $(\text { plein })^{12}$ yang fungsinya hampir memiliki kesamaan dengan sebuah taman.

Pada 1919 dibangun Ijzerman Park. Taman tersebut dibangun untuk mengenang jasa-jasa Dr.Ir.J.W. Ijzerman yang telah berandil dalam merancang dan memimpin pemasangan jalur kereta api, dari Bogor ke Bandung. Pada tahun yang sama dibangun pula Molukkenpark. Pada 1920, setidaknya telah terdapat tiga buah taman, yaitu Tjitaroemplein, Tjilakiplein, dan Oranjeplein. Oranjeplein merupakan pusat lingkungan pemukiman di ujung tenggara Rioustraat (Jalan Riau). Lalu pada tahun 1920, sebuah lapangan di depan gedung Departement van Oorlog dijadikan sebagai sebuah taman tropis, taman tersebut kemudian diberi nama Insulide Park pada tahun 1925. Adapun untuk memperingati hari jadi Gemeente Bandoeng, dibangun Jubileum Park pada tahun 1923 (Mooi Bandoeng, 1933-1934 dan Kunto, 1986: 368-370).

Selain taman-taman yang telah disebutkan di atas, terdapat pula beberapa

\footnotetext{
12 Plein adalah lapang yang luas, biasanya ditanami dengan rerumputan. Hampir memiliki kesamaan karakter dengan taman, namun perancangannya lebih sederhana. Sebagian besar plein hanya berupa lapangan rumput saja. Namun ada beberapa plein yang dirancang dengan kerumitan dan komposisi layaknya sebuah taman, seperti Oranjeplein dan Tjitaroemplein.
} 
plein di Kota Bandung, namun beberapa plein $^{13}$ yang ada ini belum dapat dipastikan tahun pembuatannya karena belum ditemukan sumber yang menyebutkan angka pasti. Selain itu, sebagian besar plein hanya berupa lapangan rumput yang hijau tanpa penataan yang khusus seperti halnya sebuah taman, kecuali penataan yang lebih detil seperti diperlihatkan oleh keberadaan Tjitaroemplein dan Oranjeplein. Dalam buku Semerbak Bunga di Bandung Raya disebutkan bahwa beberapa plein yang terdapat di Bandung, antara lain Orchideeplein, Houtmanplein, Limburg Stirumplein, Pandawaplein, Rotgansplein, dan Sabangplein. Keberadaan taman-taman tersebut sudah tercantum dalam peta Perencanaan Kota Bandung yang dibuat pada tahun 1933.

Pembangunan taman-taman kota ini memiliki pola-pola tertentu dalam penempatan serta persebarannya. Untuk mengamati pola-pola persebaran taman kota ini, maka perlu dilihat dari pola atau penempatan pemukiman penduduk di kota Bandung. Pemukiman penduduk ini meliputi penduduk pribumi, Eropa, dan Timur Asing. Masyarakat Eropa memiliki keunggulan tersendiri dibandingkan dengan masyarakat lainnya. Begitupun dengan tata letak taman yang ditetapkan berdasarkan letak pemukiman Eropa.

Pihak pemerintah memiliki peranan yang sangat dominan dalam mengatur pola pemukiman di kota Bandung. Secara garis besar pola pemukiman masyarakat di kota Bandung pada masa kolonial terpisah antara bagian Bandung Utara dan Bandung Selatan. Bandung Utara sebagian besar merupakan daerah yang dihuni oleh sebagian besar masyarakat Eropa, yang dibatasi dengan rel kereta api (Lubis, 2003: 438). Kehadiran para pejabat pemerintah

\footnotetext{
${ }^{13}$ Pemisahan lokasi pemukiman memang telah terjadi jauh sebelumnya berdirinya Gemeente Bandung, paling tidak sejak tahun 1860-an, yaitu setelah Kota Bandung menjadi pusat pemerintahan Keresidenan Priangan (1864) (Hardjasaputra, 2000: 53).
}

kolonial yang berbangsa Belanda menyebabkan gambaran relief pola kota lebih berkembang. Pola pemukiman kota menunjukkan secara jelas pencerminan adanya pluralisme masyarakat, yang juga menunjukkan stratifikasi sosial masyarakat kolonial Hindia Belanda (Soekiman, 2000: 208). Pemukiman khusus orang-orang Eropa, umumnya tinggal berkelompok, yaitu pada bagian terpilih dari kota, yang biasanya terletak di tepi jalan-jalan besar kabupaten, terpisah dari tempat tinggal pribumi.

Pada periode 1910-an hingga 1930-an, perumahan Eropa telah memiliki permukiman yang terkonsentrasi di sekitar wilayah Bandung Utara seperti daerah Nylandweg (Cipaganti sekarang), kawasan Fokkerhuis di sekitar Andir, sekitar Riouwstraat, Menadostraat (Jalan Aceh sekarang), Jalan Papandayan, sekitar Dennenlust Hoofdweg (Jalan Hegarmanah sekarang), daerah sekitar Insulinde Park, daerah sekitar Gedung Sate, hingga meliputi daerah Dagoweg dan sekitarnya. Daerah ini sering juga disebut sebagai wilayah pusat kegiatan masyarakat Eropa (Europeesche Zakenwijk) (Hariyono, 2006: 74). Kompleks pemukiman yang memiliki daerah yang unik pada awal abad ke-20 adalah pemukiman sekitar Riouwstraat yang dikenal sebagai kompleks Kapitein Hill. Sejak dimulainya perancangan Kota Bandung, yaitu pada 1918 dilakukan perencanaan pemukiman elit orang-orang Eropa, pemukiman ini meliputi daerahdaerah yang telah dikemukakan di atas, termasuk pula kompleks Jaarbeurs. Kemudian pemukiman Eropa ini meluas hingga daerah Wastukencana, Merdikaweg (Jalan Merdeka sekarang), Cihampelas, Rembrandtstraat (Jalan Dipenogoro sekarang), Tjitaroemstraat (Jalan Citarum sekarang), Tjilakistraat (Jalan Cilaki sekarang), Lembangweg (Jalan Setiabudi sekarang), Parkweg (Jalan Taman Sari sekarang), hingga Beatrix Boulevard (Jalan Dipati Ukur sekarang). 


\section{Analisis Spatial}

Beberapa taman kota yang ada di Bandung memang sengaja dirancang dan ditempatkan di lingkungan masyarakat Eropa. Taman-taman kota ini tersebar di Bandung Utara, yang merupakan sebuah kawasan yang bergaya Tropische Stad, yaitu terdiri atas bangunan-bangunan serta perumahan yang tergolong mewah dan modern bagi masyarakat Eropa. Berdasarkan analisis Peta Perencanaan Kota Bandung tahun 1933 dan berdasarkan data taman yang ada hingga tahun 1925 dapat diketahui pola-pola persebaran taman di sekitar lingkungan masyarakat Eropa, khususnya pada taman-taman yang sudah dikenal di Kota Bandung meliputi Pieter Sijhoff Park, Ijzerman Park, Molukken Park, Insulinde Park, Jubileum Park, Tjitaroemplein dan Oranjeplein.

Wilayah yang meliputi Tropische Stad adalah jaringan jalan yang memanjang di sebelah kanan dan kiri Riouwstraat. Di wilayah ini, setidaknya terdapat tiga buah taman yang tersebar di kanan dan kiri jaringan jalan sepanjang Riouwstraat. Taman-taman tersebut antara lain Molukkenpark, Tjitaroemplein, dan Oranjeplein.

Posisi Oranjeplein, Molukkenpark, dan Tjitaroemplein terhubung melalui tiga jalan utama. Ketiga taman tersebut, masing-masing berdekatan dengan fasilitas-fasilitas masyarakat Eropa. Misalnya, Molukkenpark berdekatan dengan lapangan olahraga Gelora dan Bangunan Jaarbeurs ${ }^{14}$. Sementara itu, Tjitaroemplein berdekatan atau berada di belakang Departement Verkeer \& Waterstaat (Gedung Sate sekarang) yang saat itu merupakan bangunan resmi instansi Pemerintah Pusat Kolonial Belanda. Kedudukan taman yang begitu

\footnotetext{
${ }^{14}$ Jaarbeurs adalah bursa tahunan, yang secara rutin diselenggarakan pada bulan Juni-Juli di Bandung. Pertama kali diselenggarakan pada 1920. Jaarbeurs menyajikan segala macam pameran, dari hasil kerajinan rakyat sampai barang-barang produksi dari industri maupun perusahaan-perusahaan.
}

berdekatan dengan lingkungan masyarakat Eropa nampak begitu jelas, seperti juga terlihat di sekitar Oranjeplein. Taman ini sengaja dibangun sebagai pelengkap dari fasilitas perumahan mewah, Kapitein Hill $^{15}$. Kompleks perumahan sekeliling Oranjeplein yang dibangun oleh Ir. D.H. Ton, merupakan wilayah perbatasan paling timur Kota Bandung. Dengan demikian, akses bagi masyarakat Eropa di Kapitein Hill ke Oranjeplein sangatlah mudah.

Keberadaan taman yang berdekatan dengan perumahan mewah memang cukup penting. Menurut H.F. Tillema, standar kelayakan sebuah rumah itu bergantung pada baik atau buruknya penataan sanitasi dan kelengkapan fasilitas. Kelengkapan fasilitas ini di antaranya meliputi jalan, lapangan, dan taman. Tersedianya fasilitas-fasilitas tersebut menentukan harga jual sebuah rumah (Budiman, 2010: 63).

Salah satu aspek menarik dari keberadaan Oranjeplein adalah posisinya yang juga cukup berdekatan dengan pemukiman pribumi golongan menengah yang berada di sekitar Kampemenstraat (Jalan Cihapit sekarang). Hal ini membuka kemungkinan bahwa orang pribumi pun memiliki kemudahan akses untuk menuju ke Oranjeplein. Perlu diketahui bahwa sebagian besar pemukiman golongan pribumi begitu berjauhan dengan fasilitasfasilitas seperti taman kota. Pemukiman pribumi, seperti kawasan Karapitan, Babakan Surabaya, Babakan Tarogong, maupun Babakan Cianjur, berada cukup jauh dari wilayah Bandung Utara yang

15 Pada sekitar tahun 1920, pemerintah membangun pemukiman 2 lantai di sekitar Oranjeplein, pemukiman tersebut tergolong sangat mewah pada saat itu. Komplek perumahan ini disebut Kapitein Hill (Akhmad G, 2007: 57). 
merupakan pemukiman masyarakat Eropa dengan fasilitas yang lengkap. Dengan demikian, keberadaan kawasan Kampemenstraat yang cukup berdekatan dengan sebuah taman kota, yaitu Oranjeplein adalah pengecualian bagi sebagian kecil golongan menengah pribumi.

Wilayah Bandung Utara didominasi oleh pemukiman dan fasilitas lengkap bagi masyarakat Eropa sehingga di wilayah ini terdapat beberapa poros pemukiman yang menjadi pusat lingkungan masyarakat Eropa, beberapa di antaranya adalah Kapitein Hill, Fokkerhuis di sekitar Andir, Europeesche Zakenwijk di sekitar Insulinde Park, dan pemukiman pegawai pemerintah di sekitar Departement Verkeer \& Waterstaat (Gedung Sate sekarang). Di beberapa poros pemukiman tersebut terdapat pula beberapa taman kota. Misalnya sekitar Insulinde Park. Kawasan ini merupakan inti dari wilayah terbangun di Kota Bandung yang memiliki identitas jalan dengan nama-nama kepulauan di Nusantara (Kunto, 1986: 288). Kematangan dan kecermatan dalam menata pemukiman di sekitar Insulinde Park telah menjadikan wilayah pemukiman di sekitar Insulinde Park ini sebagai prototipe Indische Koloniaal Stad (Dienaputra, 2004: 18). Perwujudan Indische Koloniaal Stad terlihat dari pemukiman di sekeliling Insulinde park yang cenderung digunakan sebagai lingkungan pemukiman militer. Tepat di sekeliling Insulindepark, setidaknya terdapat sembilan bangunan yang digunakan untuk keperluan militer, antara lain: (1) Gedung Departement Van Oorlog (Gedong Sabau), (2) Gedung Sekolah Hoogere Burgerschool di Bilitonstraat (Jalan Belitung), (3) Rumah Komandan Ajudan Jenderal, (4) Menara Sekolah MULO di Javastraat (Jalan Jawa), (5) Rumah Komandan Divisi, (6) Dua bangunan Mess Perwira, (7) Gereja Pieters Kerk, (8) Rumah Komandan Garnisun.
Pada Insulinde Park hampir keseluruhan lahannya dikelilingi oleh Departement Van Oorlog (Kementerian Peperangan), di samping itu posisi Insulinde Park cukup dekat dengan Pieter Sijhoff Park. Kedua taman ini, kurang lebih berjarak 0,3 kilometer ${ }^{16}$. Dua taman ini dihubungkan oleh dua jalan utama, yaitu Menadostraat dan Merdikaweg. Jika Insulinde Park berdekatan dengan Departement Van Oorlog, maka Pieter Sijhoff Park berdekatan dengan Kantor Gemeente Bandoeng dan Gedung De Javesche Bank. Pola demikian menampakkan bahwa kawasan antara Pieter Sijhoff Park hingga Insulinde Park merupakan kawasan pemerintahan dan lingkungan pemukiman militer yang sengaja dibangun dengan memadukan gedung-gedung pemerintahan dengan lahan hijau.

Perpaduan antara bangunan atau kawasan pemerintahan dengan lahan hijau atau taman nampak lebih jelas di sekitar Tjitaroemplein dan sepanjang Rembrandtsraat. Kawasan Rembrandtstraat hingga ke arah utara menuju kawasan Beatrix Boulevard merupakan wilayah yang sengaja disediakan Gemeente Bandung untuk dibangun sebagai kawasan Gouvernement Bedrijven ${ }^{17}$ (Pusat Instansi Pemerintah). Bangunan-bangunan di kompleks Gouvernement Bedrijven tersebut beberapa di antaranya berdekatan dengan Tjitaroemplein dan Tjilakiplein.

\footnotetext{
${ }^{16}$ Perhitungan berdasarkan Peta Bandung tahun 1933 dengan skala 1: 10.000

${ }^{17}$ Perancangan konstruksi dan denah tata letak bangunan perkantoraan dilakukan oleh V. L. Slors dibantu oleh J. Gerber. Pembangunan kawasan perkantoran pemerintahan ini dilakukan pada lahan seluas 27.000 meter. Pembangunan ini berdasarkan Raadbesluit tanggal 18 Desember 1929, yang dikukuhkan lewat surat tanggal 25 Januari 1930. Namun dari seluruh perencanaannya, Slors dan Gerber baru sempat menyelesaikan bangunan Departement Verkeer \& Waterstaat yang kini disebut Gedung Sate. (Kunto, 1986: 933).
} 
Tjitaroemplein tepat berada di belakang Departement Verkeer \& Waterstaat yang terhubung ke sebelah utara melalui Tjiratoemstraat. Adapun posisi Tjilakiplein berada di sebelah timur dari Departement Verkeer \& Waterstaat yang terhubung melalui Rembrandtsraat. Sementara itu, posisi Tjilakiplein berdekatan atau berhadapan langsung dengan Laboratorium Geologie en Mijnwezen (Laboratorium Pusat Geologi dan Pertambangan). Tidak jauh dari posisi kedua taman tersebut, yaitu dari Departement Verkeer \& Waterstaat terdapat penataan ruang yang simetris, berupa poros selatan-utara (menuju ke arah utara), merupakan sebuah boulevard yang lebar mengesankan, dengan jalur pertamanan indah memanjang di tengah (Kunto, 1986: 936).

Selain taman-taman yang telah dikemukakan di atas, terdapat pula beberapa taman yang kedudukannya lebih sebagai lapangan hijau atau biasa disebut plein. Sebagian besar plein tersebar di sekitar Kapitein Hill atau berada di sebelah barat dari jaringan jalan Haoutman Straat (Jalan Supratman sekarang), taman-taman tersebut antara lain: Van Limburg Stirum Plein, Orchidee Plein, Tjampaka Plein, dan Houtman Plein. Adapun plein lainnya terdapat di wilayah Europeesche Zakenwijk (sekitar Insulinde Park) yaitu Sabang Plein di Sabang weg. Di wilayah sekitar Fokkerhuis terdapat pula dua buah plein yaitu Pandawa Plein di jaringan jalan sebelah selatan Burgemeester Copsweg (Jalan Padjadjaran sekarang), dan Rotgan Plein di jaringan sebelah selatan Pasteurweg (Jalan Pasteur sekarang).

Pemaparan di atas menunjukkan bahwa terjadi harmonisasi antara bangunan atau fasilitas yang ada dengan tamantaman kota. Selain itu juga terlihat bahwa memang beberapa poros lingkungan masyarakat Eropa, hampir selalu terdapat taman-taman kota. Hal serupa dapat dilihat pula dari keberadaan Ijzerman Park. Taman ini merupakan bagian dari bangunan Technische Hoogeschool (sekarang ITB). Technische Hoogeschool sebagai suatu lingkungan pendidikan memperlihatkan bahwa perancangannya mengikutsertakan lahan hijau. Tidak jauh dari Ijzerman Park terdapat sebuah taman, yaitu Jubileum Park. Kedua taman ini, kurang lebih berjarak 0,15 kilometer $^{18}$. Posisi Jubileum Park terletak di bagian barat dari Ijzerman Park yang dihubungkan oleh Hogeschoolweg (Jalan Ganesha sekarang). Hampir setiap taman yang ada, tidak berdiri sendiri, namun selalu terhubung dengan taman lainnya yang jaraknya berdekatan, juga tamantaman tersebut saling melengkapi dengan bangunan di sekelilingnya untuk menunjukkan keindahan lahan hijau. Hal ini menampakkan suatu pola yang menarik, yaitu taman-taman kota, khususnya taman-taman kota utama yang berukuran besar, ternyata tersebar dalam poros-poros atau kelompok-kelompok tersendiri. Setidaknya terdapat tiga poros utama taman-taman kota di Bandung utara.

Poros pertama yaitu taman yang terdapat sekitar di Merdikaweg menuju Menadostraat di sebelah utara, taman tersebut meliputi Pieter Sijhoff Park dan Insulinde Park. Kedua taman tersebut mengakomodasi lingkungan pemerintahan.

Gambar 1. Letak Pieter Sijhoff Park dan Insulinde Park

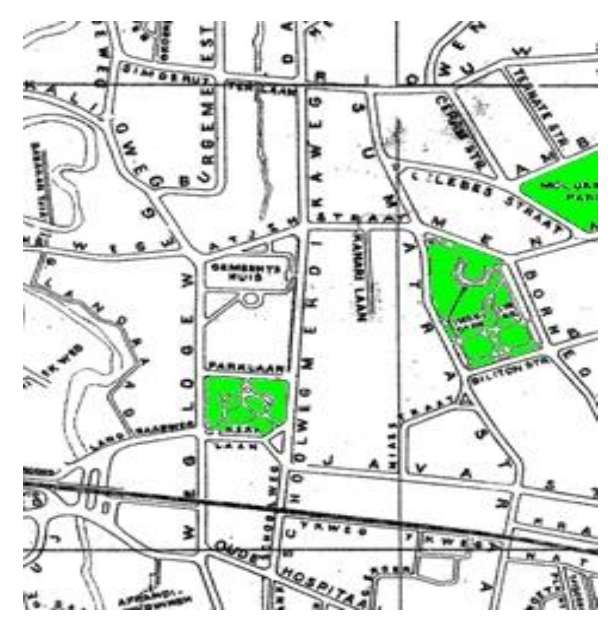

${ }^{18}$ Perhitungan berdasarkan Peta Bandung tahun 1933 dengan skala 1: 10.000 
Sumber: Bandoeng Town Plan Second Edition 1933, ANRI

Poros kedua adalah taman-taman di sekitar Kapiteinhill hingga Wilhelmina Boulevard. Taman-taman tersebut, secara berurutan meliputi Oranjeplein, Molukken Park, dan Tjitaroem Plein. Poros ketiga adalah dua taman yang dihubungkan oleh Hogeschoolweg, yaitu Ijzerman Park dan Jubileum Park.

Gambar 2. Letak Ijzerman Park dan Jubileum Park

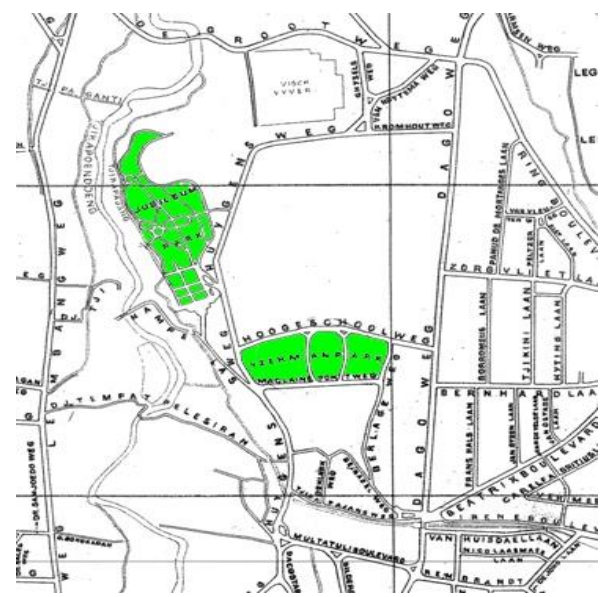

Sumber: Bandoeng Town Plan Second Edition 1933, ANRI

Ketiga poros taman-taman tersebut selalu berdekatan dengan fasilitas atau bangunan bagi masyarakat Eropa, baik itu berupa pemukiman, gedung-gedung pusat pemerintahan, maupun lingkungan pendidikan.

Berdekatannya taman dengan perkantoran milik Pemerintah Hindia Belanda di masa itu boleh jadi hal yang biasa diterapkan di Kota Kolonial lainnya. Rudolf Mrazek (2006) menyebutkan istilah dienst park yang berarti taman dinas. Ia menyebutkan mengenai keberadaan tamantaman di sekitar kantor dinas administrator perkebunan atau di sekitar rumah administrator. Tulisan Mrazek tentang taman dinas tersebut mengacu pada catatan Profesor M. W.F. Treub atas kunjungannya ke Djatoroto, Jawa Timur. Selain di Jawa Timur, Treub pun menyebutkan taman dinas yang berada di Batavia (Mrazek, 2006: 99-100).

Berdasarkan taman-taman kota yang ada beserta bangunan-bangunan di sekitarnya dapat dikatakan bahwa taman kota merupakan bagian yang cukup penting dalam perancangan karena tamantaman tersebut dibangun dengan sistemnya tersendiri, yaitu ada perpaduaan antara bangunan, jalan, dan taman itu sendiri dalam menciptakan lingkungan yang indah. Hal ini menjadi sangat masuk akal karena awal abad ke-20 merupakan awal perkembangan sistem taman dalam perancangan kota yang modern, khususnya di Eropa dan Amerika. Hal ini sejalan dengan esai yang ditulis oleh Sonja Dümpelmann, "The Park International: Park System Planning as An International Phenomenon at The Beginning Of The Twentieth Century"'19.

Sangatlah mungkin bahwa cukup banyaknya persebaran taman kota di Bandung sepanjang tahun 1919 hingga 1925, ikut dipengaruhi oleh kemajuan pengetahuan akan sistem taman itu sendiri. Sebagaimana yang terjadi di Eropa pada awal abad ke-20 sebagai periode awal perkembangan sistem taman dalam perancangan kota modern. Adapun porosporos taman kota yang terdapat di Bandung Utara memang memperlihatkan konsep kota taman. Konsep tersebut

19 Pengakuan akan fungsi sistem taman memperoleh momentum bersamaan dengan kematangan perkembangan keindahan kota pada dekade pertama awal abad ke-20. Ide dalam menghubungkan jalur taman dan boulevard yang terhubung dengan seluruh taman utama kota dan poin menarik dalam menerangkan perkembangan yang terjadi itu, mengacu pada kombinasi antara kegunaan dan keindahan dalam pembangunan kota. Pada awal abad ke-20, Amerika Utara dan Eropa mengakui akan pentingnya sistem taman (www.ghi-dc.org/publications diakses 18 Juli 2009 ). 
diadopsi oleh Gemeente Bandung dari rancangan kota taman yang terdapat di Eropa, khususnya di Inggris. Haryoto Kunto (1986) mengibaratkan konsep perancangan kota Bandung pada masa Hindia Belanda seperti konsep kota concentric circle yang dikemukakan oleh Ebenezer Howard, suatu bentuk kota yang ditata berlapis-lapis, melingkari pusat kota yang tepat berada di tengah. Pusat-pusat kota yang dimaksud adalah pusat kota yang di dalamnya terdapat kompleks Balai Kota, Gedung Pertemuan Umum, dan Pusat kebudayaan. Kemudian pada lapisan kedua terdapat lahan-lahan hijau, dan pada lapisan terluar terdapat lahan pertanian dan hunian penduduk pedesaan.

Kebijakan perancangan kota yang dilaksanakan oleh pemerintah Hindia Belanda ini, selain menunjukkan keindahan lahan hijau melalui tamantaman kota yang ada, namun sekaligus menegaskan pola pembangunan yang lebih difokuskan pada lingkungan masyarakat Eropa.

\section{Taman Kota dalam Rencana Perluasan Kota}

Selepas tahun 1925 , tidak banyak ditemui perkembangan yang berarti dalam keberadaan taman kota. Suatu perkembangan taman-taman kota di Bandung baru terjadi sejalan dengan rencana perluasan kota, atau dikenal dengan sebutan Plan Karsten. Sebutan Plan Karsten sendiri diambil dari nama Ir. Thomas Karsten, selaku perancang dalam rencana perluasan kota Bandung. Plan Karsten yang dikenal pula sebagai Uitbreidingsplan Stadsgemeente Bandoeng (Rencana Perluaan Kotapraja Bandung) mencakup rencana perluasan wilayah administratif kota. Rencana tersebut diterapkan guna mengantisipasi perkembangan kehidupan di Kota Bandung yang terus meningkat, juga mengantisipasi perkembangan penduduk.

Mengenai pertambahan penduduk Eropa, hal tersebut terkait erat dengan rencana dijadikannya Bandung sebagai ibu kota Hindia Belanda sehingga jumlah pejabat atau pegawai bangsa Belanda semakin bertambah. Pada tahun 1920, jumlah penduduk Eropa mencapai 9.043 orang, lalu mengalami peningkatan yang cukup pesat pada tahun 1930, yaitu mencapai 19.327 orang (Hardjasaputra, 2000). Mengantisipasi pertambahan jumlah penduduk, sejak 1930 Plan Karsten mulai disusun dan direncanakan. Menurut rencana yang disusun, dikemukakan bahwa dalam waktu 25 tahun wilayah Kota Bandung diperluas sampai 12.758 hektar, dengan asumsi bahwa penduduk kota akan mencapai \pm 750.000 jiwa pada tahun 1935 . Untuk mengkaji rencana tersebut, pemerintah pusat membentuk Commissie voor de Bevordeeling van den Uitbredingsplannen der Gemeente Bandoeng (Komisi Penilai Rencana Pemekaran Gemeente Bandung). Dalam empat poin hasil penilaian komisi tersebut, salah satu poin mengemukakan bahwa: perlunya segera diambil langkah-langkah untuk menyebarkan penduduk dari pusat-pusat kegitan secara seimbang ke berbagai penjuru kota. Agar kota memiliki banyak pusat kegiatan penduduk (Hardjasaputra, 2000: 14 )

Pusat-pusat kegiatan penduduk yang dimaksud ini boleh jadi termasuk pula taman-taman kota atau lapanganlapangan hijau, layaknya taman kota yang biasa disebut plein. Berbagai plein yang ada, berdasarkan pada peta tahun 1933, memang banyak tersebar di beberapa penjuru kota. Taman atau plein memang lazimnya digunakan sebagai pusat kegiatan masyarakat atau pun untuk tempat rekreasi.

Perluasan wilayah Kota Bandung yang direncanakan Karsten bukan sematamata dikaitkan dengan standar kepadatan penduduk, tetapi lebih condong pada pertimbangan untuk mendapatkan luas kota yang ideal, memenuhi syarat sebagai Tuinstad (Kota Taman) yang banyak memerlukan lahan hijau terbuka di dalam kota (Kunto, 1984: 40)

Plan Karsten yang direalisasikan di Bandung memang sejalan dengan 
rencana Gemeente Bandoeng, yang menginginkan penataan Kota Bandung menjadi sebuah Tuinstad. Plan Karsten ini setidaknya mengakomodasi tiga konsep pokok perancangan Kota Bandung, yaitu: (1) Membangun kota menjadi prototipe sebuah koloniaalstad (kota kolonial), (2) Menata dan menghijaukan kota dalam upaya mewujudkan tuinstad (kota taman), (3) Mempersiapkan Bandung sebagai ibu kota Hindia Belanda. Salah satu penataan yang dimaksud adalah penataan tamantaman kota. Melalui bantuan dari perkumpulan Bandoeng Vooruit, sepanjang 1930 hingga 1935, taman-taman kota di Bandung berusaha diubah menjadi Mini Botanical Garden. Sejumlah biaya telah dikeluarkan oleh perkumpulan itu untuk melengkapi pohon dan tanaman di tamantaman dengan plat aluminium, mencantumkan nama jenis tumbuhan bersangkutan dalam Bahasa Latin, Sunda, dan Melayu (Kunto, 1986: 295).

Di bawah penilikan botanikus Dr. L. Van der Pijl, pemberian plat nama pada pohon dan tanaman dalam taman-taman kota dapat dirampungkan dalam waktu dua tahun (Jaarverslag van de Vereeniging Bandoeng Vooruit, 1934 dalam Kunto, 1986: 295). Selain pemberian nama pada tanaman-tanaman, tidak banyak ditemui perkembangan yang berarti. Salah satu perkembangan yang cukup mencolok terjadi di Jubileum Park. Taman yang dibangun pada tahun 1923 ini awalnya digunakan untuk menanam berbagai jenis tanaman langka, namun sejak tanggal 12 April 1933, sekitar 13,6 hektar lahan taman dijadikan Bandoeng Zoological Park (sekarang Kebun Binatang Bandung) (Tresnawati, 2008: 50). Taman ini yang sejatinya merupakan pengembangan dari Jubileum Park, mengalami pengembangan pada 1934 hingga 1936, berupa penambahan 58 kelompok jenis binatang dari seluruh dunia. Keberadaan Bandoeng Zoological Park memberi nuansa baru dalam pilihan objek wisata bagi para wisatawan (Suganda, 2007:154).
Sementara itu, rencana perluasan Kota Bandung yang juga mencakup penataan kota Bandung menjadi Tuinstad (Kota Taman), belum dapat terlaksana secara sepenuhnya, mengingat pada tahun 1942 terjadi Perang Dunia II. Ir. Thomas Karsten, selaku perancang rencana perluasan kota, meninggal dunia di tahun 1942, dalam kamp interniran Jepang di Kota Bandung.

\section{PENUTUP}

Konsep taman di Hindia Belanda bisa ditelusuri sejak pejabat-pejabat VOC membangun kehidupan di luar benteng, di Batavia, pada abad ke-16. Awalnya taman dikenal hanya taman milik pribadi. Konsep taman pribadi ini sesuai dengan perkembangan perancangan taman di Eropa dari abad ke-15 hingga ke-17. Konsep taman kota atau taman yang digunakan oleh publik baru muncul ketika revolusi industri terjadi.

Orang-orang Eropa, khususnya para elit (pejabat dan pengusaha perkebunan) membangun kota tempat tinggalnya di Hindia Belanda, sesuai dengan cara pandang mereka di tempat asalnya. Perkembangan taman kota di Bandung didorong oleh peranan elit-elit Eropa ini. Sepanjang tahun 1918-1925 taman-taman kota dibangun di Bandung sebagai komponen penting rencana perpindahan ibu kota Hindia Belanda. Dalam perancangan kota Bandung di masa itu, taman selalu disertakan berdampingan dengan lingkungan perumahan, lingkungan pendidikan, dan lingkungan kantor-kantor pemerintah. Hal ini memperlihatkan bahwa orang Eropa melihat perkembangan kota yang baik, harus disertai dengan pemeliharaan dan penyediaan lahan hijau/alam yang sama baiknya.

\section{DAFTAR SUMBER \\ 1. Arsip}

Bandoeng Town Plan Second Edition. 1933, ANRI. 
Verslag van der Toestand der Gemeente Bandoeng over de Jaren 1906/1918, Perpustakaan Nasional.

\section{Makalah, Skripsi, dan Tesis}

Budiman, Hary Ganjar. 2010.

Taman Kota di Bandung (1885-1942).

Skripsi. Bandung: Universitas

Padjadjaran.

Dienaputra, Reiza. 2004

Bandung 1906-1970; Studi tentang Perkembangan Ekonomi Kota, Makalah disajikan pada "The 1st Internasional Conference on Urban History", Surabaya: 23-25 Agustus.

Hardjasaputra, Sobana . 2002.

Perubahan Sosial di Bandung 1810-1906. Disertasi, Depok: FIB UI

Hariyono, Agung. 2007.

Perkembangan Gaya dan Bentuk Rumah Tinggal di Kota Bandung. Skripsi. Jatinangor: Jurusan Sejarah Fakultas Sastra Universitas Padjadjaran.

Maulana, Suhardi. 2002.

Seremban Urban Park, Malaysia: A Preference Study.Tesis. Blacksburg: College of Architecture and Urban Study.

\section{Buku}

Kunto, Haryoto. 1984.

Balai Agung Kota Bandung: Granesia. . 1984.

Wajah Bandoeng Tempo Doloe. Bandung: Granesia.

1986.

Semerbak Bunga di Bandung Raya.: Granesia.

Kuper, Adam dan Jessica Kuper. 2000.

Ensiklopedi Ilmu-ilmu Sosial. Jakarta: Raja Grafindo Persada.

Lubis, Nina Herlina, Kunto Sofianto, Ietje Marlina, Sobana Hardjasaputra, Reiza D. Dienaputra, Mumuh Muhsin Z. 2000.

Sejarah Kota-kota Lama di Jawa Barat. Jatinangor: Alqaprint

Mrazek, Rudolf. 2006.

Engineers of Happy Land; Perkembangan Teknologi dan
Nasionalisme di sebuah Koloni. Jakarta: Yayasan Obor Indonesia.

Nas, Peter J.M. 2007.

Kota-kota Indonesia; Bunga Rampai. Yogyakarta: Gadjah Mada University Press.

Rogers, Elizabeth Barlow. 2001.

Landscape Design: A Cultural and Architectural History. New York: Harry N. Abrams, Inc.

Soekiman, Djoko. 2011.

Kebudayaan Indis: dan Gaya Hidup Masyarakat Pendukungnya di Jawa (Abad XVII-Medio XX). Jakarta: Komunitas Bambu.

Suganda, Her. 2007.

Jendela Bandung; Pengalaman Bersama Kompas. Jakarta: Kompas.

Tresnawati, Titin. 2008

Industri Pariwisata di Bandung Masa Hindia-Belanda (1898-1942). Skripsi. Jatinangor: Fakultas Sastra Universitas Padjadjaran.

\section{Internet}

Dümpelmann, Sonja.

"The Park International: Park System Planning as An International Phenomenon at The Beginning Of The Twentieth Century" diakses dari www.ghi-dc.org/publications, Tanggal 18 Juli 2009

Kompas.

"Janji Ridwan Kamil untuk Tahun 2015 , dari Taman sampai Monorel" diakses dari

http://regional.kompas.com/read/2014/0 9/16/13041431/janji.ridwan.kamil.untuk .tahun.2015.dari.taman.sampai.monorel , diakses Tanggal 25 Februari 2015.

NN.

"Public Park and Garden in Manchester" diakses dari http://www.manchester2002uk.com/daytrips/parks-gardens.html, Tanggal 4 Juni 2015

http://www.europecities.com/en/786/netherland s/amsterdam/place diakses Maret 2010 . 